\title{
The Effect of Leadership Effectivity, Education and Training and Career Development to the Performance of Lecturers at University of Riau Kepulauan Batam
}

\author{
Ramon Zamora ${ }^{1, *}$, R. Madhakomala ${ }^{2}$, Hamidah $^{3}$ \\ ${ }^{1}$ Student of Post Graduate Universitas Negeri Jakarta (UNJ) Indonesia \\ ${ }^{2,3}$ Senior Lecturer of Post Graduate Universitas Negeri Jakarta (UNJ) Indonesia \\ *Corresponding author. Email: author@example.com
}

\begin{abstract}
This research to determine and analyze the factors Leadership Effectivity, Education and Training and Career Development on Employee Performance at Unversity of Riau Kepulauan Batam. Results Data collection obtained sample of 117 respondents. Respondents in this study were Lectures of Unversity of Riau Kepulauan Batam. The analytical method used is multiple regression analysis, using Pearson rank validity test and Cronbach-Alpha reliability test against research instrument. To assess the influence of Leadership Effectivity, Education and Training and Career Development influence on employee performance at Unversity of Riau Kepulauan Batam, used path analysis. After doing research and testing show Leadership Effectivity, Education and Training and Career Development have positive and significant effect to Lecturer Performance.
\end{abstract}

Keywords: Leadership Effectivity, Education and Training, Career Development, Work Lecturer Performance

\section{INTRODUCTION}

University of Riau Batam Islands is one of the Higher Education Institutions in Indonesia, which plays an important role in producing graduates who have the competence and quality to meet the needs of the industrial world and have the ability to compete in the world of work.

The success of Riau Islands University is largely determined by good human resource management activities. Improving the quality of Human Resources is carried out through lecturers where the position of lecturers in national development in the field of education is explicitly stated in article 3 paragraph (1) of Law No. 14 of 2005 concerning teachers and lecturers that lecturers have a position as professionals at the level of higher education in accordance with the laws and regulations.

The reality in the field today as a preliminary study of the performance of lecturers is different from what should be. The deviation of lecturers' performance is experienced by many universities, especially private universities. One of them is the lack of readiness of lecturers in mastering the material in the teaching process so that students lack the depth of knowledge, another problem that arises is the lack of results of research conducted by time lecturers focused on the number of teaching hours.

Many factors that influence the level of performance of lecturers include leadership effectiveness, education and training and career development. A career is a pattern of experiences related to work throughout one's life. For a lecturer, a career is a reflection of success in the field because career is a reflection of the responsibilities, desires, interests, skills, and skills of each individual.

Based on the background that the author has described above, the existing problems can be identified as follows; 1) The performance of lecturers is still low in achieving the goals set and cannot yet work optimally and lack of sense of responsibility due to lack of encouragement to excel. 2) Programmed education and performance-based training cannot be implemented consistently, while the measurement of the performance of the lecturers themselves cannot be implemented fairly. 3) Lecturer careers are still unclear as seen from the absence of openness and criteria in positioning students in higher education. 4) the commitment of lecturers to the organization is still low, this is indicated by the lack of 
lecturer efforts in implementing Tridharma. 5) The work environment that is not conducive makes the morale and work motivation of the lecturers decrease. 6) Motivation of lecturer work is still low, as can be seen from there are still many lecturers who only carry out teaching assignments and ignore other tasks such as research and service. 7) Organizational work culture is less applied by lecturers such as lecturers tend to avoid responsibility, and tend to blame each other, 8) Frequent conflicts occur both fellow lecturers and leaders due to feelings of mutual suspicion and loss of trust. 9) The level of education, ability and knowledge of most lecturers is generally still in the second level.

\section{THEORETICAL FRAMEWORK}

\subsection{Performance}

Some experts suggest the notion of performance like the concept of performance of a worker in his job, according to certain criteria for playing a job and a conceptual framework for analyzing workplace tasks. Performance according to [2] comes from the word job performance or actual performance, namely work performance or actual achievement achieved by someone. So performance is the result of work in quality and quantity that employees achieve in carrying out their duties in accordance with the full sense of responsibility given to them.

Furthermore, performance is as a result or the level of success of a person as a whole during a certain period in carrying out tasks compared to various possibilities, such as work results standards, targets or targets or criteria that are determined in advance and agreed upon. On the other hand, [2], defines that performance as a success rate expressed by function and motivation and ability. According to Stoner, the employee's performance can be judged from two points of view, that is efficient and work effectiveness.

\subsection{Leadership Effectiveness}

The power is necessary in terms of the power of influence and influence of the activists of followers toward goal achievement. that it gives leaders the ability to influence others. Likewise, according to Claude [1], the effectiveness of leadership in policy making is a leader of conscious, thoughtful thinking that includes judgment and selection among numbers of alternatives. [3] stated that the leadership of rational thought leaders either individually or in groups in all forms of organization.

The effectiveness of leadership in implementing policies is a cycle of activities that lead rational thinking in both individuals and groups at all levels and forms of organization. Terry [11] describes the effectiveness of leadership in decision-making is alternative choice and two or alternatives exist.

\subsection{Training Education}

According to [4] Education is a long-term activity that uses systematic and organized procedures in which managerial employees learn conceptual and theoretical knowledge to achieve common goals, and training is a short-term educational process that uses systematic and organized procedures in which non-managerial employees learn the knowledge and technical capabilities in limited goals. Whereas according to [8] training is a method used to provide or improve the skills needed to carry out work now. While education is more oriented towards the future and emphasizes more on increasing one's ability to understand and interpret knowledge.

According to [2] education is related to increasing general knowledge and understanding of our environment as a whole. While Exercise is an effort to increase the knowledge and expertise of an employee to do a job.

\subsection{Career Development}

According to Mathis and Jackson [7] a career is a series of positions that are related to the work one occupies throughout his life. While career development according to [10] is the process of improving individual work, capabilities achieved in order to achieve the desired career. [5] suggested that Career development, from the standpoint of the organization, is the porcelain activity which helps individuals plan their future career within the enterprise, in order to help the enterprise, achieve and the employee achieves maximum selfdevelopment.

Career development, from an organizational point of view, is a porcelain activity that helps individuals plan their future careers within the company, to help companies and employees achieve maximum selfdevelopment). Career development is a condition that indicates an increase in one's status in an organization in the career path that has been determined in the organization concerned [6].

\subsection{Conceptual Framework}

Based on the problem formulation and literature review described in the previous chapter, the conceptual framework of research refers to relevant theories and previous studies. As a comprehensive picture of the interrelationship between variables used in the research model, below is presented a chart of the research conceptual framework. Where the research framework can be described in (Figure 1) as follows:

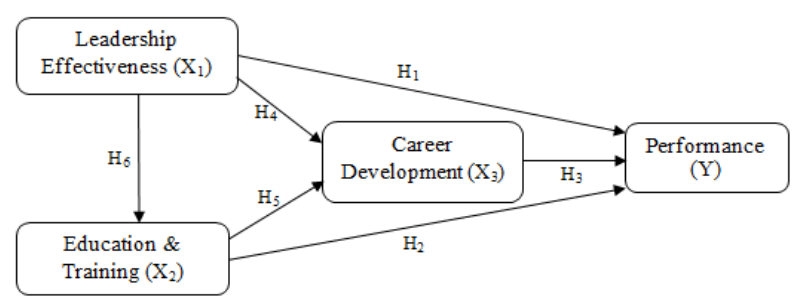

Figure 1. Conceptual Framework 
Based on the above study and the theoretical framework described above, the research hypothesis is formulated as follows:

1) Effectiveness of leaders directly influences Performance

2) Education and training have a direct effect on performance

3) Career development directly influences Performance

4) Effectiveness of leaders has a direct effect on career development.

5) Education and training have a direct effect on career development.

6) Effectiveness of leaders has a direct influence on education and training.

\section{RESEARCH METHOD}

This study uses multiple linear regression analysis and path analysis. The number of samples studied was 117 respondents. The choice of this method is based on the consideration that research involves 4 variables whose data comes from a group of respondents who are the same and answer every question that is asked simultaneously and simultaneously. Research approach with quantitative methods, this is used to analyze the influence of several independent variables used on the dependent variable. The research variables used are the Effectiveness of Leadership (X1), Education and Training (X2), Career Development (X3), and Lecturer Performance (Y).

\section{ANALYSIS}

The data description of the research results begins with a data presentation on the variables of Leadership Effectiveness (X1), Education and Training (X2), and Career Development (X3) and Lecturer Performance (Y). The data obtained in the field and statistically processed into a frequency distribution list with many classes are calculated according to the rules of Sturges. The explanation of each variable's data is as follows:

\subsection{Leadership Effectiveness}

Descriptive statistics calculation results obtained that leadership effectiveness variables have a mean value of 106.5 with standard deviation of 0.396 , mode 104 and median 106. Based on the results of the frequency distribution of the most absences in the interval 101-109 class which is 35 respondents and the relative frequency is $40.23 \%$. Whereas, the smallest absolute frequency is found in the 73-82 interval class of 1 respondent with a relative frequency of $1.15 \%$.

\subsection{Education and Training}

The results of descriptive statistics calculation showed that the Education and Training variables had a mean value of 105.98 with a standard deviation of 0.386 , mode 105 and a median of 105 . Based on the frequency distribution of the highest absences in the 97-105 interval class, as many as 46 respondents and its relative frequency $52.87 \%$. Whereas, the smallest absolute frequency is found in the 77-87 interval class of 5 respondents with a relative frequency of $5.75 \%$

\subsection{Career Development}

Descriptive statistical calculation results obtained that Career Development variables have a mean value of 100.25 with a standard deviation of 0.336 , mode 105 and median 101. Based on the absolute frequency distribution in the interval class $102-110$, there were 38 respondents and the relative frequency was $43.68 \%$. Whereas, the smallest absolute frequency is found in the interval class $120-129$ as many as 2 respondents with a relative frequency of $2.30 \%$

\subsection{Employee Performance}

The results of descriptive statistical calculations obtained that the variable employee performance has a mean value of 107.5 with a standard deviation of 0.345 , mode 107 and median 107. Based on the frequency distribution of the most absences in the interval class 100108 , there were 32 respondents and the relative frequency was $36.78 \%$. Whereas, the smallest absolute frequency is found in the 127-135 interval class as many as 7 respondents with a relative frequency of $8.05 \%$.

\subsection{Test Analysis Requirements}

Before stepping into testing hypotheses, it must first go through calculation analysis requirements. Testing the analysis requirements used consisted of three types, namely the normality test, and the linearity test. The following will be described one by one the results of the tests conducted

\subsection{Normality Test}

The normality test aims to determine the distribution of errors obtained by normal distribution or not. The normality test was carried out in the study using the Lilliefors test. The results of the above normality test are summarized in Table 1 below:

Table 1. Summary of Normality Test Estimated Error

\begin{tabular}{|c|c|l|c|c|}
\hline No. & $\begin{array}{c}\text { Estimated } \\
\text { Error }\end{array}$ & L count & $\begin{array}{c}\text { L table } \\
(0.05)\end{array}$ & Information \\
\hline 1 & Y on $\mathrm{X}_{1}$ & 0.015 & 0.082 & Normal \\
\hline 2 & Y on $\mathrm{X}_{2}$ & 0.013 & 0.082 & Normal \\
\hline 3 & Y on $\mathrm{X}_{3}$ & 0.024 & 0.082 & Normal \\
\hline 4 & $\mathrm{X}_{3}$ on $\mathrm{X}_{1}$ & 0.018 & 0.082 & Normal \\
\hline 5 & $\mathrm{X}_{3}$ on $\mathrm{X}_{2}$ & 0.041 & 0.082 & Normal \\
\hline 6 & $\mathrm{X}_{1}$ on $\mathrm{X}_{1}$ & 0.068 & 0.082 & Normal \\
\hline
\end{tabular}

Source: Processing data from research results

Tests for normality requirements can be met by all empirical data of each variable, so the use of a normal distribution table in changing the calculation data of the hypothesis test can be used. 


\subsection{Linearity Test}

The results of the test for significance and linearity of regression are presented in the following table:

\section{RESULTS}

\subsection{Positive Direct Effect of Leadership Effectiveness on Lecturer Performance}

Table 2. Significance Test Results and Regression Linearity Test

\begin{tabular}{|c|c|c|c|c|}
\hline \multirow{2}{*}{ Regression } & \multicolumn{2}{|c|}{ Significance Test } & \multicolumn{2}{|c|}{ Linearity Test } \\
\hline & F count & F table $\alpha=0.05$ & F count & F table $\alpha=0.05$ \\
\hline Y on $X_{1}$ & $15.124 * *$ & 4.12 & $0.786^{\mathrm{ns}}$ & 2.11 \\
\hline $\mathrm{Y}$ on $\mathrm{X}_{2}$ & $14.549 * *$ & 4.12 & $0.717^{\mathrm{ns}}$ & 2.11 \\
\hline $\mathrm{Y}$ on $\mathrm{X}_{1}$ & $74.75 * *$ & 4.12 & $0.735^{\mathrm{ns}}$ & 2.11 \\
\hline $\mathrm{X}_{3}$ on $\mathrm{X}_{2}$ & $53.53 * *$ & 4.12 & $0.879^{\text {ns }}$ & 2.11 \\
\hline $\mathrm{Y}$ on $\mathrm{X}_{3}$ & $11.62 * *$ & 4.12 & $1.03^{\mathrm{ns}}$ & 2.11 \\
\hline $\mathrm{X}_{2}$ on $\mathrm{X}_{1}$ & $179.82 * *$ & 4.12 & $0.837^{\mathrm{ns}}$ & 2.11 \\
\hline
\end{tabular}

From the calculation results, the test of regression significance and linearity as seen in the table above, shows that the F-count value is greater than F-table, thus it can be concluded that all regression equations are linear

\subsection{Model Testing}

Calculations for path coefficients using the SPSS version 22 program. Path diagrams have 6 path coefficients, namely Py1, Py2, Py3, P31, P32, P21 so that the results of all calculations and tests are obtained as a summary of the following table:

Table 3. Research Path Coefficient

\begin{tabular}{|l|l|l|l|l|l|l|}
\hline No. & Path & \multirow{2}{*}{$\begin{array}{c}\text { Path } \\
\text { Coefficent }\end{array}$} & T count & \multicolumn{2}{|c|}{$\mathrm{T}$ table } & \multirow{2}{*}{ Information } \\
\cline { 5 - 6 } & & & & 0.05 & 0.01 & \\
\hline 1 & $\mathrm{P}_{\mathrm{y} 1}$ & 0.157 & 4.026 & 1.98 & 2.63 & Significant \\
\hline 2 & $\mathrm{P}_{\mathrm{y} 2}$ & 0.155 & 3.083 & 1.98 & 2.63 & Significant \\
\hline 3 & $\mathrm{P}_{\mathrm{y} 3}$ & 0.211 & 3.970 & 1.98 & 2.63 & Significant \\
\hline 4 & $\mathrm{P}_{31}$ & 0.409 & 4.407 & 1.98 & 2.63 & Significant \\
\hline 5 & $\mathrm{P}_{32}$ & 0.271 & 3.409 & 1.98 & 2.63 & Significant \\
\hline 6 & $\mathrm{P}_{21}$ & 0.289 & 5.756 & 1.98 & 2.63 & Significant \\
\hline
\end{tabular}

Based on the results of the calculation of the table above, it can be illustrated in each of the coefficient variable paths for empirical model research shown in the following figure.

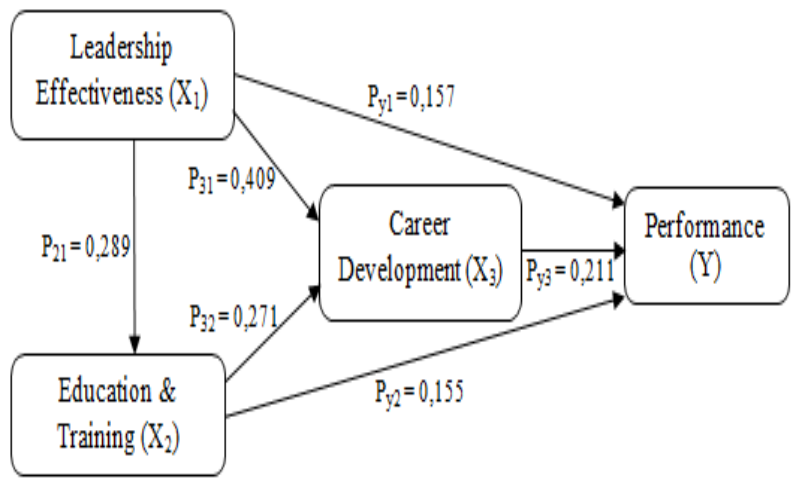

Figure 2. Empirical Model of Inter-Variable Structural Relations Based on Path Analysis Results.
Based on the results of analysis and data processing conducted in this study, it can be seen that all the paths in the developed model structure have a significant positive correlation which can be interpreted that the above model developed can be used to predict performance in the Riau Islands University environment. The findings from the above analysis can be drawn from the conclusion that the variables of leadership effectiveness, education and training and career development affect the performance of lecturers. The difference depends on the size of the contribution of each variable in influencing the level of performance. From the results of the analysis and the method used that the variables that have a contribution to the size of the influence are based on the coefficient values obtained from the survey results then data processing is done, namely standardized beta $(\beta)$ coefficients. Leadership effectiveness has a significant influence on performance, namely with a beta value of 0.157 standardized. This proves that leadership effectiveness factors in organizations contribute to the effect on performance. The directives and policies applied will affect the performance of the lecturer.

\subsection{Positive Direct Effect of Education and Training on Lecturer Staff Performance.}

The results of the above analysis show that education and training affect the performance of lecturers at Riau Islands University. Education and training variables have a significant effect on performance with a beta value of 0.155 standardized. This proves that the factors of education and training in organizations contribute to the influence of employee performance

\subsection{Positive Direct Effect of Education and Training on Lecturer Staff Performance.}

The results of the above analysis show that Education and Training have an effect on the Career Development of lecturers in the Riau Archipelago Batam University environment. The Education and Training Variables have a significant effect on Career Development with a beta value of 0.271 standardized. This proves that the Education and Training factors in the organization contribute to the influence of the Lecturer Career Development. Based on the description and processing of 
the statistical data above, it can be defined as having a positive direct influence on Education and Training on Lecturers Career Development.

\subsection{Positive Direct Effect of Education and Training on Lecturer Staff Performance.}

The results of path analysis to determine the positive influence and significance between Career Development and performance shows that there is a strong enough effect, namely the standardized beta coefficient value of 0.211 . The strong contribution of the variable influence of Career Development on performance because of these variables including intervening and proved in the study to have a high correlation and significance. So that it can be revealed that the Career Development of employees can improve the performance of lecturers in the University of Riau Islands Batam. The relevance between performance and Career Development cannot be separated because these two variables are interrelated because they are equally dependent variables but depend on the independent variables that support them. Because in this research study the performance variable is a variable that depends on Career Development, the success of the organization measured by performance will be influenced by the level of Career Development in the University of Riau Islands Batam.

\subsection{Positive Direct Effect of Education and Training on Lecturer Staff Performance.}

Leadership Effectiveness is one of the variables related to Career Development and can even directly affect Career Development. Because the Leadership Effectiveness is good at improving employee careers. The closeness of the relationship and its significant effect can be seen from the hypothesis test which found that there is a standardized beta value of 0.409 the effect of Leadership Effectiveness on Career Development. From the description and processing of statistical data the results of the study can be defined as that there is a positive direct effect of Leadership Effectiveness on Career Development.

\subsection{Positive Direct Effects of Leadership Effectiveness on Education and Training.}

The results of analysis and processing of survey data developed with the above model show that the Effectiveness of Leadership has an effect on Education and Training at the Riau Islands University of Batam. The Effectiveness of Leadership Variables has a significant effect on Education and Training which is a beta value of 0.289 which is standardized. This turned out to have the greatest positive correlation than the influence of other variables on the measured dependent variable. Thus, the results of the study show the results that result that the appropriate leadership effectiveness can improve education and training.

\section{CONCLUSION}

Based on the results of the analysis and discussion above, it can be concluded that the research theoretical model is supported by the following data. There is a positive direct effect of leadership effectiveness on the performance of lecturers, meaning that the increase in leadership effectiveness in appropriate implementation leads to an increase in lecturer performance. Then there is a positive direct effect of education and training on the performance of lecturers, meaning that the increase in education and training of lecturers causes an increase in the performance of lecturers. Furthermore, there is a positive direct effect of career development on employee performance, meaning that the increase in lecturer career development causes an increase in lecturer performance. Likewise, there is a positive direct effect of leadership effectiveness on the development of lecturers 'careers, meaning that leadership effectiveness in the appropriate implementation leads to an increase in lecturers' career development. Furthermore, there is a positive direct effect of education and training on career development of lecturers, meaning that increasing education and training of lecturers leads to an increase in lecturers 'career development, and there is a positive direct effect of leadership effectiveness on lecturers' education and training, meaning increased leadership effectiveness in appropriate implementation leads to increased education and lecturer training.

\section{REFERENCES}

[1] Calquitt LePine, Wesson. Organizationbal Behavior, second edition. New York: McGraw-hill. George, Claude, S. The History of Management Thought. New Jersey: Prentice-Hall. 2009.

[2] Gibson J. L et al. Organization Behavior Structure Processes. Philipiness: Mc Graw Hill Hasibuan, S.P. Melayu. Manajemen Sumber Daya Manusia. Edisi Revisi. Jakarta: Bumi Aksara. 2006.

[3] Hoy, K. W., \& Miskel, C. Educational Administration: Theory, Research, and Fachce. New York: Random House Inc, 2008.

[4] Mangkunegara, A.P. Manajemen Sumber Daya Manusia Perusahaan, cetakan pertama. Bandung: PT. Remaja Rsodakarya, 2004.

[5] Mangkunegara, A.P. Manajemen Sumberdaya Manusia Perusahaan. Bandung: Remaja Rosdakarya. Mangkunegara, A.A. Anwar. (2011). Manajemen Sumber Daya Manusia Perusahaan. Bandung: Remaja Rosda Karya, 2007.

[6] Martoyo, Susilo. Manajemen Sumber Daya Manusia. Yogyakarta: BPFE. 2007.

[7] Mathis Robert L. dan Jackson John H. Human Resource Management, alih bahasa. Salemba Empat. Jakarta. 2006.

[8] Panggabean, S., Mutiara. Manajemen Sumber Daya Manusia. Bogor: Ghalia Indonesia. 2004. 
[9] Rival, V. Performance Appraisal, Sistem yang Tepat untuk Menilai Kinerja Karyawan dan Meningkatkan Daya Saing Perusahaan. Jakarta: Rajawali Press. 2005.

[10] Stphen, P. Robbins. Perilaku Organisasi. Edisi Indonesia Jilid 1. Jakarta: Indeks, Gramedia Grup. Sudiro, Achmad. (2011). Perencanaan Sumber Daya Manusia. Malang: UB Press. 2007.

[11] Terry, George R. Human Resorce Management, Ten Edition. New York: McGraw-Hill. 2009. 